British Journal of Education

Vol.8, Issue 3, pp.161-177, March 2020

Published by ECRTD- UK

Print ISSN: ISSN 2054-6351

Online ISSN: ISSN 2054-636X

\title{
EXPLORING SELF-REGULATED WRITING PROCESS OF EFL LEARNERS
}

\author{
Jingjing Hu \\ School of Foreign Languages, Sun Yat-sen \\ Email: hujj25@mail.sysu.edu.cn
}

\section{Li Yi}

School of Foreign Languages, Sun Yat-sen

Email: yili3@mail.sysu.edu.cn

\begin{abstract}
This study explored the self-regulated writing process of EFL learners in the context of China. Drawing upon the writing diaries written by 109 Chinese university EFL learners, the study examined how Chinese EFL learners self-regulated their writing in the pre-, while-, and post- writing phases. The findings showed that the learners went through ten processes (i.e., goal setting, knowledge activation, strategic planning, environmental preparation, organizing ideas and structures, preparing for good mental states, monitoring, controlling, reflection, and reaction) in the three writing phases to selfregulate not only their cognition, but also their behaviours, and the learning context/environment. Subprocesses of each of the ten processes were also identified. This study expanded self-regulated learning theory and L2 writing theory and contributed to a better understanding of how EFL learners learn to write. It is expected to inform L2 writing teaching, and to shed light on future L2 writing research.
\end{abstract}

KEYWORDS: self-regulated writing, writing process, EFL writing, self-regulation

\section{INTRODUCTION}

Self-regulated learning (SRL) refers to the process of using meta-strategies (e.g., planning, monitoring, controlling, reflecting, etc.) to self-regulate learners' cognition, motivation, behaviour, and learning environment (Pintrich, 2000; Zimmerman, 2000). It has been viewed as a key competence for successful learning. Evidence shows that SRL is significantly associated with self-efficacy, learning motivation, and academic performance (Finkbeiner, Knierim, Smasal, \& Ludwig, 2012; Pintrich, 2004). For this reason, great efforts have been made to identify SRL processes (e.g., Bown \& White, 2010), aiming to inform the development of SRL pedagogical schemes. The results of relevant studies indicate that SRL processes exist at both macro and micro levels, differ across learner groups, and have different effects on learning (Greene \& Azevedo, 2009). 
British Journal of Education

Vol.8, Issue 3, pp.161-177, March 2020

Published by ECRTD- UK

Print ISSN: ISSN 2054-6351

Online ISSN: ISSN 2054-636X

Despite the wide investigations of SRL in various disciplines, with it commonly emphasized as an important paradigm in educational and psychological research for decades (Pintrich, 2000; Zimmerman, 1986; 2000), it has not come into EFL researchers' attention until recently (Tseng, Dornyei, \& Schmitt, 2006). Little has been known about the SRL process for L2 writing learning. To expand self-regulated learning and L2 writing theories, to contribute to a better understanding of L2 writing learning, and to inform the development of L2 writing pedagogical scheme, this study gauged the processes and subprocesses of EFL learners' self-regulated writing process in the context of China.

\section{THEORETICAL FRAMEWORK}

The investigation of EFL writing process draws upon SRL theory as the theoretical framework. A number of SRL models have been developed, among which Zimmerman's (2000) cyclical phase model has been the most commonly adopted one in SRL research (Panadero, 2017). Drawing upon socio-cognitive theories, Zimmerman's model classifies phase structures and sub-processes of self-regulation. In this model, SRL is divided into three cyclical and iterative phases: forethought, performance, and self-reflection. During the forethought phase, self-regulated learners go through the processes of task analysis and self-motivation. They control and observe their own learning behaviours during the phase of performance and judge the learning effectiveness, and then react to the judgement in the last phase of SRL - self-reflection. Each process involves sub-processes, such as goal setting and strategic planning in the process of task analysis process, as well as selfinstructing, imaging, and attention focusing in the process of controlling. Following Zimmerman's SRL models (1989; 2000), Pintrich (2000) proposed an SRL framework, indicating that self-regulated learners self-regulate four aspects (i.e., cognition, motivation/affect, behavior, and the learning context) throughout the SRL phases (i.e., forethought, planning, activation; monitoring; controlling; reaction, and reflection).

A number of investigations have been conducted for the self-regulated processes and subprocesses of learning specific subject matters. These studies have verified, enriched, expanded, or modified the conceptualization of SRL (e.g., Greene \& Azevedo, 2009; Hu $\&$ Gao, 2018). For example, with a series of research, Azevedo and his colleagues gauged learners' self-regulation processes of learning complex topics in hypermedia environments. They identified the processes of 'planning', 'monitoring', 'strategy use', 'handling of task difficulty and demands', and 'interest activities', as well as 35 specific SRL sub-processes (Greene \& Azevedo, 2009). The findings of the study has enabled a large number of subsequent studies, which examined learners' behaviours and difficulties during a particular SRL process (e.g., Jang, 2017), effects of the processes on a variety of variables involved in learning (e.g., Nicolás-Conesa, Roca de Larios, \& Coyle, 2014), as well as the effectiveness of instructional methods on SRL development (e.g., Ferreira, Simão, \& da Silva, 2017; Wang, 2017). 
British Journal of Education

Vol.8, Issue 3, pp.161-177, March 2020

Published by ECRTD- UK

Print ISSN: ISSN 2054-6351

Online ISSN: ISSN 2054-636X

\section{L2 Writing Process Research}

In the early 1980s, L2 researchers and educators started to highlight the importance of understanding how the writing products came into being on the development of L2 writing pedagogy (Zamel, 1983). Since then, L2 writing process research has emerged and thrived (e.g., Chen, 2015; Zamel, 1983). Relevant studies mainly focus on learners' cognitive processes, such as idea generation, goal setting, evaluating or revising (e.g., Beauvais, Olive, \& Passerault, 2011; Ong, 2014; Wang, 2017). For example, Chen (2015) examined the cognitive processes 30 Taiwan EFL learners experienced in an email task. The study identified a number of strategies involved in the learners' processes of showing email writing intention (e.g., showing interest, making promises and giving compliments), paying attention to the vocabulary, grammar and the content of the situations, planning (e.g., planning a general direction and the specific utterances) and evaluation (e.g., evaluation of politeness and evaluation of the persuasiveness of their reasons). Hayes and Berninger (2014) proposed a framework of cognitive process of writing, which included four cognitive processes: proposing, translating, evaluating, and transcribing. During the process of proposing, a package of ideas for inclusion in the writings is generated in nonverbal form. The ideas were then translated into verbal form of expressions which were represented as grammatical strings of language in the translating process. In the transcribing process, the grammatical strings were organized into a written text. In the evaluating process, the ideas and language produced in previous processes were examined. In recent years, studies exploring L2 writing process from sociocultural perspectives have emerged, with the focus on L2 learners' processes of using environmental and social resources for writing. For example, Lei (2016) explored how EFL learners used resources for their writing. Eight Junior English majors from a key university in Mainland China participated in the study. The analysis of interviews, stimulated recalls, and process logs revealed that the student writers went through the processes of noticing, imitating and goal setting. Similarly, Hu and Gao (2018) investigated into the process of using environmental and social resources for EFL writing of six secondary school learners in bilingual education contexts. They identified more SRL processes, namely, noticing, selecting, reorganizing, evaluating understanding, reviewing and memorizing, imitating, as well as adapting.

Despite the fact that writing process has been one of the major themes in L2 writing research (Pelaez-Morales, 2017; Riazi, Shi, \& Haggerty, 2018), self-regulated writing process has seldom been discussed. To fill the gap, this study investigated Chinese EFL learners' writing processes and subprocesses within the framework of SRL, aiming to contribute to a better understanding of L2 writing process and to inform L2 writing learning and teaching. The following research question was addressed:

What are the processes and sub-processes of Chinese EFL learners' self-regulated writing? 
British Journal of Education

Vol.8, Issue 3, pp.161-177, March 2020

Published by ECRTD- UK

Print ISSN: ISSN 2054-6351

Online ISSN: ISSN 2054-636X

\section{METHODOLOGY}

The study explored the self-regulated writing process of EFL learners from a Chinese university. In China, English is taught as a key curriculum subject from Grade Three of primary school and remains as a compulsory course for undergraduate non-English-majors. The students enrolled in this university got high scores in GaoKao (the National University Entrance Examination). Having received education in Mainland China, a highly competitive and examination-oriented educational context for more than a decade, the students tended to regard good performance in the examinations as one of their major learning goals.

\section{The Participants}

The participants in the study were 109 Year One students from three schools, who were assigned to three classes for the university English courses taught by the same lecturer. When the study was conducted, they had two consecutive 45 minutes' classes each week throughout the semester and were required to write an argumentative essay as the assignments of the course. They were also asked to write a diary after writing the essay to record their writing process. They understood that the diaries were to help the lecturer know about their learning process for the purpose of writing teaching enhancement, that what they put in the diary would not affect their course score, and that their personal information would not be disclosed when the findings were disseminated.

\section{Data Collection}

Prompts were provided to the participant students to facilitate the recording of their writing process. The prompts composed of questions about writing behaviours related to the writing tasks, including the preparatory work they did before writing, their while-writing performance, and the post-writing behaviours. Questions included 'Did you set goals for the writing task before writing? If yes, what goals did you set?', 'Did you think about the strategies for completing the writing task before writing? If yes, what strategies did you think about?', 'Did you do any other things before you wrote, which were related to the writing task? If yes, what did you do?' 'Did you observe and control your own writing process? If yes, what did you do?', 'Did you reflect and react to your writing performance? If yes, what did you do?', 'Did you do any other things for the completion of the writing task? If yes, what did you do?'. The prompts and the diaries were written in the participants' first language, Chinese. Informal interviews with the students were also conducted for the clarification of unclear information in the diaries. Notes were taken during the interviews.

\section{Data Analysis}

Informed by SRL and L2 writing studies (Du-Babcock \& Feng, 2018; Zimmerman, 2000), the writing diaries were first segmented into the three writing phases, namely pre-writing, while-writing, and post-writing. Each segment was then coded deductively into processes with the guidance of SRL models (Pintrich, 2000; Zimmerman, 2000) and the processes 
British Journal of Education

Vol.8, Issue 3, pp.161-177, March 2020

Published by ECRTD- UK

Print ISSN: ISSN 2054-6351

Online ISSN: ISSN 2054-636X

identified in L2 writing research. The emergence of new codes were allowed. Then inductive analysis was conducted for the identification of sub-processes of the processes identified. During the process, the texts were coded into basic-level concepts of EFL writing process, such as 'to use more variety of vocabulary', 'checking the reliability of information', and 'thinking about text structure', etc. Similar concepts were then grouped into a category (Corbin \& Strauss, 2014). For example, the concepts such as 'to use more variety of vocabulary', 'to ensure the accuracy of grammar', and 'to write more complex sentences' were grouped into 'setting linguistic goals'. A number of processes and subprocesses of self-regulated EFL writing were finalized throughout the three phases of writing, which will be illustrated in the following sections.

\section{FINDINGS}

With example data extracts, this section illustrates the self-regulated EFL writing processes and subprocesses that our participants experienced in pre-, while-, and post- writing phases. The processes and subprocesses will also be summarized in Table 1.

\section{Pre-Writing Processes}

In their diaries, the students reported six processes they experienced before they wrote, including setting goals, activating prior knowledge and relevant experience, planning for the writing strategy, preparing the environment for writing, organizing ideas and structure, and preparing for good mental states.

\section{Setting goals}

Setting goals for writing was found to be an effective instructional practice for teaching writing (Graham \& Perin, 2007). It was also identified as a learning process of selfregulated learners (Lei, 2016). In this study, four types of writing goals were identified, namely linguistic goals, textual goals, ideational goals, and task-specific goals. Our participants set goals to improve the accuracy, conciseness, and complexity of the language used in their essays, such as 'to avoid using Chinglish' (e.g., S4\#1, S23\#3), 'to use accurate words' (e.g., S5\#1, S9\#2, S26\#3), 'to reduce the grammatical mistakes' (e.g., S7\#1, S20\#2, S18\#3), 'to use more rhetorical devices' (e.g., S14\#1), 'to use more concise language' (e.g., S19\#1, S9\#2, S24\#3), 'to reduce simple sentences and use more clauses' (e.g., S22\#1, S26\#2, S8\#3), 'to use some newly-learnt vocabulary' (e.g., S25\#1, S22\#2, S15\#3), etc. Textual goals referred to their target to improve the text structure, coherence, and cohesiveness, such as 'to make my writing more logical and coherent' (e.g., S6\#1, S8\#2, S5\#3). The ideational goals involved the reliability, richness, and novelty of the contents. Examples were 'to avoid making up facts' (e.g., S6\#1), 'to show the major differences between Chinese and American culture' (e.g., S16\#1, S33\#2, S20\#3), etc. Our participants were also found to set goals to meet task-specific requirements, such as the time and word limits. It is worth noting that our students tended to apply the requirements commonly shared by their past examinations when no time or words limits were set for this writing 
British Journal of Education

Vol.8, Issue 3, pp.161-177, March 2020

Published by ECRTD- UK

Print ISSN: ISSN 2054-6351

Online ISSN: ISSN 2054-636X

task. For example, they attempted to write more than 300 words (e.g., S13\#1, S17\#2, S29\#3), or to 'finish the writing within 30 minutes (e.g., S30\#1, S14\#2, S41\#3).

\section{Activating prior knowledge and relevant experience}

Activation of prior knowledge is assumed to be one process in the first SRL phase (Mak \& Wong, 2017; Pintrich, 2000). Our participants were found to activate their linguistic, textual, and ideational knowledge before writing the essays. They activated the linguistic knowledge such as vocabulary, expressions, and grammar that can be used in the writing: I recalled the sentence patterns I've learnt. (S8\#1)

I was thinking whether the sentences I had recited in high school could be used or not. (S8\#3)

They thought about the structure and organization of the essay. The textual knowledge activated could be typical format and structure of argumentative essays or the evaluation criteria of important examinations such as GaoKao.

I thought about the structure of the essay and the sentence patterns that I could use. (S20\#1) I recalled the usual format, writing strategy, and layout of typical argumentative writings. (S4\#2)

They also activated their knowledge about the content of the topic, thinking about what they knew about the topic and what could (not) be written in the essay:

I recalled what I wrote about for similar tasks before. (S43\#3)

I recalled the content in the sample essays on this topic I've read in high school. (S18\#3)

Moreover, they activated their knowledge of possible resources they could use:

I could use the resources such as online reports and academic articles, and I could also ask others. (S22\#1)

I considered whether the writing templates I learnt before could be used in this writing task. (S36\#3)

Some students were also found to activate their knowledge about the problems identified in their previous writing experience, so that they would plan for the learning strategies accordingly:

I thought of the mistakes I've made in previous writings. (S2\#3)

I did not have much knowledge about the subjects... So I need to do some research before writing. (S22\#1)

\section{Planning for writing strategy}

Self-regulated learners experience strategic planning in the first phase of SRL process (Zimmerman, 2000), which was proven to be closely associated with course grade (Artino Jr, Cleary, Dong, Hemmer, \& Durning, 2014). In this study, strategic planning was also identified as a pre-writing process. The students were found to take efforts to think about ways of improving the language, text structure, and the ideas for the essays:

I planned to search the internet or asked someone for classical misunderstandings of the values first, and then select two of them that impress me the most. (S6\#1) 
British Journal of Education

Vol.8, Issue 3, pp.161-177, March 2020

Published by ECRTD- UK

Print ISSN: ISSN 2054-6351

Online ISSN: ISSN 2054-636X

I would read some English articles related with this topic and learn some expressions, and then make an outline. (S23\#3)

\section{Preparing the environment for writing}

Despite the importance of the interaction between learners and the learning environment argued by socio-cognitive and literacy researchers (Chamberlain, 2019; Parry \& Taylor, 2018; Pintrich, 2000; Zimmerman, 2000), it has not received much attention as a part of SRL process in empirical studies until recently (Hu \& Gao, 2018). The analysis of the diaries indicated that preparing the environment for writing was a process in the pre-writing phase reported by most of the students (88/109). During the process, they thought about, obtained and used relevant resources. The resources mentioned the most included the internet, e-dictionaries, textbooks, and so on. The students also assessed whether the environment was appropriate for the writing. If not, they would initiatively adjust it, by switching off the mobile phone (e.g., S29\#2), keeping apart from the internet (e.g., S6\#2), going to the library (e.g., S20\#3), looking for a quieter place (e.g., S13\#3), for instance.

\section{Organizing ideas and structures}

After activating their knowledge about the topic of an essay and/or gaining new ideas from resources, some students (e.g., S2\#1, S6\#2, S8\#3) organized them into logical structures with the methods of outlining, sequencing the ideas, and even making detailed plans about what or how to write in each part.

I made an outline briefly and choose three main points to make further elaborations. (S24\#2)

I firstly decided what are the three major differences in values (between Chinese and American culture) and then elaborated them in details part by part. (S32\#2)

\section{Preparing for good mental states}

Four students in our study reported to relax themselves mentally and physically to prepare for good mental states before writing. Two of them (S19\#3 and S17\#3) took a shower; one (S31\#3) relaxed herself and kept positive; the other (S40\#3) took a nap to make sure that he had the best mental state for doing the writing task.

\section{While-Writing Processes}

As reported in the diaries, our participants experienced the processes of monitoring and controlling while writing the essays. They monitored and controlled their cognition, behaviors, and environment for writing. They monitored and controlled their cognition to make sure that they were focusing on the writing tasks:

I controlled my attention in writing. (S33\#3)

They also monitored and controlled their cognition to make sure that they were using appropriate language, text structure, and ideas, and meeting the task requirements:

I corrected some spelling and grammatical mistakes while writing, and adjusted the position of some content in the whole article. (S12\#1) 
British Journal of Education

Vol.8, Issue 3, pp.161-177, March 2020

Published by ECRTD- UK

Print ISSN: ISSN 2054-6351

Online ISSN: ISSN 2054-636X

I checked the spelling and grammar of my article by Word AutoCorrect. (S2\#3)

I controlled the word limits and writing time, and made sure the content would not go to too loose or scattered. (S4\#3)

Apart from cognition, they also monitored their behaviours to appropriate their use of strategies and resources:

I monitored the effectiveness of my strategies in writing, the usefulness of the resources, and the appropriateness of my viewpoints. (S2\#1)

I observed whether word querying was helpful for my writing and whether writing by outline could facilitate the expression of my points of view. (S8\#2)

They monitored whether they behaved according to the strategic plan. If not, they adjusted instantly. For example, S13\#1 planed not to look up words in the dictionary while writing and she monitored and controlled her behaviours so that she followed the strategic plan:

I always wanted to look up words I didn't know in the dictionary, but I forced myself not to do so. (S13\#1)

Moreover, the students monitored and controlled their writing environment, observed whether the obtained linguistic and ideational resources were useful, and would change them if they were not.

I monitored whether the newly-learnt expression were properly used and whether my expression was native-like. (S29\#1)

I monitored whether I follow the outline and strategies as I planned, and felt the resources were very useful. (S20\#3)

\section{Post-Writing Processes}

Self-regulated learners are assumed to reflect on their cognition, behaviours, and learning environment, and react to the problems identified after learning (Pintrich, 2000; Zimmerman, 2000). Our students were found to reflect on the language used, the structure of the text, the content written, the progress of meeting the task requirements, the attention paid to the writing tasks, their behaviours of using planned strategies and obtained resources, and their effectiveness and usefulness of the resources. Once problems were identified, they reacted for a better quality of the essays they have written, an improvement for next writing and the long-term learning to write.

\section{Reflection}

The analysis of the diaries indicated that the students reflected on different cognitive aspects. They evaluated the accuracy, conciseness, and complexity of the language:

I evaluated the preciseness of my language, the correctness of the grammar, the fluency of the sentences, and the native-likeness of my expression. (S20\#2)

I thought about the correctness of vocabulary and grammar and the comprehensibility of the used resources. (S21\#2)

They reflected on the coherence and cohesiveness of the text:

I wrote in a low speed, and had difficulty in prioritizing the content. I could not organize the language logically, and the cohesion in my writing was not good. (S6\#1) 
British Journal of Education

Vol.8, Issue 3, pp.161-177, March 2020

Published by ECRTD- UK

Print ISSN: ISSN 2054-6351

Online ISSN: ISSN 2054-636X

They evaluated the reliability, richness, appropriateness, and novelty of the content:

I reflected on whether the argument was strong or not, and thought of finding better examples. (S20\#3)

They also reflected on the goals they set and their conformance to task-specific requirements:

I thought about the length of my article... (S28\#2)

I found that my purpose of writing was not clear. (S3\#3)

Moreover, they evaluated the attention they paid to the writing:

I could not concentrate on writing and had difficulty in composing the article... I will need more practice in the future. (S4\#2)

I reflected on...whether I had refrained from the influence of entertainment devices like mobile phone. (S14\#1)

Apart from the aforementioned cognitive aspects, the students also reflected on their behaviours of using planned strategies and obtained resources:

I reflected on whether I used the strategies successfully. (S14\#1)

I reflected on whether the time was properly managed or whether too much resources were sought. (S8\#2)

I thought about whether I had expressed all that I knew. (S1\#3)

I found that my pre-writing preparation was not enough. (S3\#3)

Moreover, they reflected on the appropriateness of their learning and writing environment, and examined whether the environmental resources were useful and whether the environment helped them to concentrate. For example, students like S12\#1 evaluated the appropriateness of resources they had obtained for writing:

I found that some prepared resources were not appropriate to be used in my article, and the resources were supposed to be selected and modified properly. (S12\#1)

I...also thought about the availability of other possible resources. (S1\#3)

S3\#2 reflected on whether the environment was good for him to focus on writing, and he found the cell phone was distracting. He reported in the diary.

I was distracted by the cell phone while writing. I should have turned down the voice of the phone. $(\mathrm{S} 3 \# 2)$

\section{Reaction}

Based on their reflection, the students revised the essays they have written to further improve the quality:

I deleted some sentences to make the article concise. (S20\#1)

I expanded the content of the article. (S17\#2)

I used Word AutoCorrect to correct the spelling and referred to the structure of the articles in textbook. (S5\#3)

They were also found to adjust their strategic plans for next writing tasks:

Next time I will prepare well, set a target, and set a time limit for writing. (S3\#1)

In next writing I should plan better and prepare an outline before writing. (S30\#2) 
British Journal of Education

Vol.8, Issue 3, pp.161-177, March 2020

Published by ECRTD- UK

Print ISSN: ISSN 2054-6351

Online ISSN: ISSN 2054-636X

As the development of writing skill is a long-term process involving the accumulation of linguistic, textual, and ideational knowledge, the students made plans, in the post-writing phase, for long-term learning to improve writing, responding to the problems they diagnosed:

I should improve my proficiency in using sentence patterns and less frequently used words, and hope to make progress in future writing. (S16\#3)

I noticed that I could not recall what I have learnt or accumulated before, so I will have more exercises. (S33\#3) 
Table 1. Self-regulated EFL writing process

\begin{tabular}{|c|c|c|c|}
\hline Phase & Process & Sub-process & Example \\
\hline \multirow{15}{*}{$\begin{array}{l}\text { Pre- } \\
\text { writing }\end{array}$} & \multirow[t]{4}{*}{ Setting goals } & Setting linguistic goals & I planned to use more variety of vocabulary. \\
\hline & & Setting textual goals & I planned to make the essay structure clear. \\
\hline & & Setting ideational goals & I planned to write more supporting details. \\
\hline & & Setting task-specific goals & I planned to complete the writing within 30 minutes. \\
\hline & \multirow{5}{*}{$\begin{array}{lr}\text { Activating } & \text { prior } \\
\text { knowledge } & \text { and } \\
\text { relevant } & \\
\text { experience } & \end{array}$} & $\begin{array}{l}\text { Thinking about the English } \\
\text { language resources that can be } \\
\text { weed for the eccav writino }\end{array}$ & $\begin{array}{l}\text { I thought about expressions that I usually used in argumentative } \\
\text { essays. }\end{array}$ \\
\hline & & Activating textual knowledge & $\begin{array}{l}\text { I thought about the classic structure for an argumentative essay, } \\
\text { which is main idea - supporting details - conclusion. }\end{array}$ \\
\hline & & $\begin{array}{l}\text { Thinking about the content } \\
\text { appropriate for the essav }\end{array}$ & I recalled the content I read about this topic. \\
\hline & & $\begin{array}{l}\text { Thinking about resources that are } \\
\text { available and useful for the }\end{array}$ & $\begin{array}{l}\text { I could refer to the CET } 4 / 6 \text { vocabulary books; I could search } \\
\text { databases for articles. }\end{array}$ \\
\hline & & $\begin{array}{l}\text { Thinking about problems they } \\
\text { had in previous writing }\end{array}$ & The words I used were often too simple. \\
\hline & \multirow[t]{3}{*}{$\begin{array}{l}\text { Planning for the } \\
\text { writing strategy }\end{array}$} & $\begin{array}{l}\text { Planning for strategies to } \\
\text { improve the language used in the }\end{array}$ & $\begin{array}{l}\text { I planned to use the dictionary to look up the English words I didn't } \\
\text { know. }\end{array}$ \\
\hline & & $\begin{array}{l}\text { Planning for strategies to } \\
\text { improve text structures }\end{array}$ & I planned to imitate the structure of the readings in the textbook. \\
\hline & & $\begin{array}{l}\text { Planning for strategies to } \\
\text { improve the content }\end{array}$ & I planned to search the internet for more ideas. \\
\hline & \multirow{2}{*}{$\begin{array}{ll}\text { Preparing } & \text { the } \\
\text { environment } & \text { for } \\
\text { writing } & \end{array}$} & $\begin{array}{l}\text { Thinking about and obtaining } \\
\text { environmental resources }\end{array}$ & I searched the internet for sample essays. \\
\hline & & $\begin{array}{l}\text { Thinking about and altering the } \\
\text { environment }\end{array}$ & I turned off my mobile phone. \\
\hline & $\begin{array}{l}\text { Organizing ideas } \\
\text { and structures }\end{array}$ & Outlining/sequencing the ideas & I wrote an outline for the essay. \\
\hline
\end{tabular}




\begin{tabular}{|c|c|c|c|}
\hline & $\begin{array}{l}\text { Preparing for } \\
\text { good mental state }\end{array}$ & Relaxing mentally and physically & $\begin{array}{l}\text { I took a nap before writing to make sure that I had a good mental } \\
\text { state. }\end{array}$ \\
\hline \multirow{7}{*}{$\begin{array}{l}\text { While- } \\
\text { writing }\end{array}$} & \multirow[t]{7}{*}{$\begin{array}{l}\text { Monitoring \& } \\
\text { Controlling }\end{array}$} & $\begin{array}{l}\text { Monitoring and controlling the } \\
\text { language used }\end{array}$ & $\begin{array}{l}\text { I kept observing the accuracy of my spelling of the words; I revised } \\
\text { the wrong spelling and grammatical mistakes while writing. }\end{array}$ \\
\hline & & $\begin{array}{l}\text { Monitoring and controlling the } \\
\text { structure of the text }\end{array}$ & $\begin{array}{l}\text { I thought about whether the ideas were logically sequenced; I } \\
\text { controlled the coherence in thinking and topic development. }\end{array}$ \\
\hline & & $\begin{array}{l}\text { Monitoring and controlling the } \\
\text { content written }\end{array}$ & $\begin{array}{l}\text { I kept checking the consistency between the content I wrote and the } \\
\text { outline I made: I made sure the content would not go to too loose or }\end{array}$ \\
\hline & & $\begin{array}{l}\text { Monitoring and controlling to } \\
\text { make sure the task requirements } \\
\text { are followed }\end{array}$ & $\begin{array}{l}\text { I monitored whether the requirements of the writing was followed; } \\
\text { I controlled the word limits and writing time. }\end{array}$ \\
\hline & & $\begin{array}{l}\text { Monitoring and controlling the } \\
\text { focus of attention. }\end{array}$ & I made 1 \\
\hline & & $\begin{array}{l}\text { Monitoring and controlling the } \\
\text { use and effectiveness of }\end{array}$ & $\begin{array}{l}\text { I observed whether word querying was helpful for my writing; I } \\
\text { forced mvself not to look up words in the dictionary while writing. }\end{array}$ \\
\hline & & $\begin{array}{l}\text { Monitoring and controlling the } \\
\text { use and effectiveness of } \\
\text { resources }\end{array}$ & $\begin{array}{l}\text { I monitored and found the obtained resources were helpful for the } \\
\text { expression. I searched for more information and added it into the } \\
\text { essay. }\end{array}$ \\
\hline \multirow[t]{5}{*}{$\begin{array}{l}\text { Post- } \\
\text { writing }\end{array}$} & \multirow[t]{5}{*}{ Reflection } & Reflection on the language & $\begin{array}{l}\text { I evaluated the preciseness of my language and the correctness of } \\
\text { the grammar. }\end{array}$ \\
\hline & & Reflection on the text structure & The cohesion in my writing was not good. \\
\hline & & Reflection on the content written & I reflected on whether the argument was strong or not. \\
\hline & & $\begin{array}{l}\text { Reflection on how well the goals } \\
\text { and task requirements were met }\end{array}$ & $\begin{array}{l}\text { I thought about the length of my article. I found my goals of writing } \\
\text { were not clear. }\end{array}$ \\
\hline & & $\begin{array}{l}\text { Reflection on the attention paid } \\
\text { to the writing task }\end{array}$ & $\begin{array}{l}\text { I could not concentrate on writing and had difficulty in composing } \\
\text { the article. }\end{array}$ \\
\hline
\end{tabular}


British Journal of Education

Vol.8, Issue 3, pp.161-177, March 2020

Published by ECRTD- UK

Print ISSN: ISSN 2054-6351

Online ISSN: ISSN 2054-636X

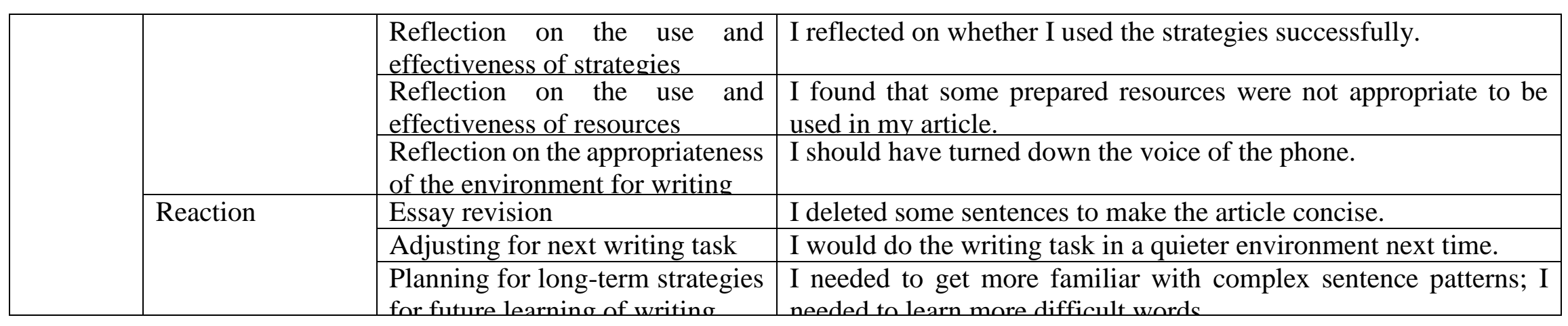




\section{DISCUSSION AND CONCLUSION}

Despite the abundance of L2 writing process research, the self-regulated EFL writing process has seldom been discussed in extant research. This study expanded and enriched L2 writing theory by exploring Chinese EFL learners' writing processes and subprocesses within SRL framework.

Ten EFL writing processes were identified in pre-, while-, and post- writing phases in this study, namely setting goals, activating prior knowledge and relevant experience, strategic planning, preparing the environment for writing, organizing ideas and structure, preparing for good mental states, monitoring, controlling, reflection, and reaction. While previous writing process research mainly focused on learners' cognitive processes (e.g., Chen, 2015; Wang, 2017), the findings of this study showed that the students also experienced processes and subprocesses to self-regulate their behaviours and contextual environment, throughout the three writing phases. During the prewriting phase, apart from the cognitive processes of setting goals and activating prior knowledge and relevant experience, the students planned for their writing behaviours (e.g., planning to imitate the structure of the readings in the textbook) and prepared the writing environment (e.g., turning off the mobile phone). While writing, they monitored and controlled the use and effectiveness of strategies and environmental resources. After writing, they further reflected and reacted on the use and effectiveness of strategies and environmental resources. This indicates that EFL writers' self-regulation of their behaviours and the writing environment is an indispensable part of their writing process. While many efforts have been made to develop the pedagogy that enhances cognitive processes such as idea generation (e.g., Fu, Lin, Hwang, \& Zhang, 2019) and reflection on text formulation (e.g., Zhang, 2018), we argue that attention should also be paid to the processes of self-regulating behaviours and environment when effective writing is being pursued.

While L2 writing research has greatly contributed to the understanding of L2 writing by identifying and examining the processes of goal setting, idea generation, idea organization, planning, evaluating, etc. (Ong, 2014; Stapleton, 2010), this study further contributed to the knowledge by identifying the subprocesses of self-regulated EFL writing processes, which indicated what types of goals the students set, what aspects of knowledge the students activated, what the students did to prepare the environment for writing, what they monitored and controlled while writing, and what they reflected and reacted on after writing. We believe that the identified self-regulated EFL writing processes and subprocesses will inform the improvement of writing learning, the development of self-regulated writing pedagogical scheme, and the design of scaffolds of self-regulated writing (Mak \& Wong, 2017). Studies can be conducted in the future to further examine the relationship between specific processes and/or subprocesses and students' writing performance.

Previous research showed that students self-regulated their motivation/affect for language learning, using strategies to identify, process, and manage their emotions (e.g., Bown \& White, 2010). No data, however, showed our participants experienced the process of motivational/affective self-regulation. This is possibly due to the fact that Chinese students' learning is most examination/score-oriented and our participants who 
Vol.8, Issue 3, pp.161-177, March 2020

Published by ECRTD- UK

Print ISSN: ISSN 2054-6351

Online ISSN: ISSN 2054-636X

were all from the key university were understandably highly motivated to complete coursework for credit points.

Monitoring and controlling, the two processes highlighted in SRL research, have received little attention in extant L2 writing research. While focusing on the postwriting processes such as evaluating and revising (e.g., Stapleton, 2010), writing researchers seem to suggest that the examination of the writing quality and the adjustment of writing behaviours happens only after the writing drafts are completed. However, this study found that the students kept observing the language, the text structure, the content in their writings, their writing behaviours, and the environment for writing during the writing process. When problems were identified, instant adjustments were made.

Reflecting on the essay quality and essay revision, the processes that were also named as evaluating and revising in previous writing research (e.g., Stapleton, 2010), were identified as two post-writing processes in this study. Apart from these processes, our participants were also found to reflect and react for future writing. They reflected on the appropriateness of the goals they set, the use and effectiveness of strategies and resources, and the suitability of environment for writing, and then adjusted their plans accordingly for next writing task and long-term strategies of learning to write. This indicated that the self-regulated learners knew that the development of writing skill was an ongoing process, and the self-regulated writing did not come to the end when a particular writing task was completed. Based on this, we argue that the research and the teaching of L2 writing should go beyond the behaviours that improves the quality of particular pieces of writing, and pay more attention to the development of self-regulated learning ability that enables lifelong learning of writing.

\section{References}

Artino Jr, A. R., Cleary, T. J., Dong, T., Hemmer, P. A., \& Durning, S. J. (2014). Exploring clinical reasoning in novices: A self-regulated learning microanalytic assessment approach. Medical Education, 48, 280-291. https://doi.org/10.1111/medu.12303

Beauvais, C., Olive, T., \& Passerault, J. M. (2011). Why are some texts good and others not? Relationship between text quality and management of the writing processes. Journal of Educational Psychology, 103(2), 415-428. https://doi.org/10.1037/a0022545

Bown, J., \& White, C. J. (2010). Affect in a self-regulatory framework for language learning. System, 38(3), 432-443. https://doi.org/10.1016/j.system.2010.03.016

Chamberlain, L. (2019). Places, spaces and local customs: honouring the private worlds of out-of-school text creation. Literacy, 53(1), 39-45. https://doi.org/10.1111/lit.12154

Chen, Y-S. (2015). Chinese learners' cognitive processes in writing email requests to faculty. System, 52, 51-62. https://doi.org/10.1016/j.system.2015.04.020

Corbin, J., \& Strauss, A. (2014). Basics of qualitative research: Techniques and procedures for developing grounded theory (4th ed.). Los Angeles: SAGE 
British Journal of Education

Vol.8, Issue 3, pp.161-177, March 2020

Published by ECRTD- UK

Print ISSN: ISSN 2054-6351

Online ISSN: ISSN 2054-636X

Publications.

Du-Babcock, B., \& Feng, H. (2018). Culture and identity on intercultural business requests: A genre-based comparative study. Ibérica, (35), 171-200.

Ferreira, P. C., Simão, A. M. V., \& da Silva, A. L. (2017). How and with what accuracy do children report self-regulated learning in contemporary EFL instructional settings? European Journal of Psychology of Education, 32(4), 589-615. https://doi.org/10.1007/s10212-016-0313-x

Finkbeiner, C., Knierim, M., Smasal, M., \& Ludwig, P. H. (2012). Self-regulated cooperative EFL reading tasks: students' strategy use and teachers ' support. Language Awareness, 21(1-2), 57-83. https://doi.org/10.1080/09658416.2011.639892

Fu, Q.-K., Lin, C.-J., Hwang, G.-J., \& Zhang, L. (2019). Impacts of a mind mappingbased contextual gaming approach on EFL students' writing performance, learning perceptions and generative uses in an English course. Computers and Education, 137, 59-77. https://doi.org/10.1016/j.compedu.2019.04.005

Graham, S., \& Perin, D. (2007). A meta-analysis of writing instruction for adolescent students. Journal of Educational Psychology, 99(3), 445-476. https://doi.org/10.1037/0022-0663.99.3.445

Greene, J. A., \& Azevedo, R. (2009). A macro-level analysis of SRL processes and their relations to the acquisition of a sophisticated mental model of a complex system. Contemporary Educational Psychology, 34(1), 18-29. https://doi.org/10.1016/j.cedpsych.2008.05.006

Hayes, J. R., \& Berninger, V. W. (2014). A cognitive process theory of writing. In B. Arfe, J. Dockrell, \& V. Berninger (Eds.), Writing Development in Children with Hearing Loss, Dyslexia, or Oral Language Problems: Implications for Assessment and Instruction (pp. 1-15). New York: Oxford University Press. https://doi.org/10.1093/acprof:oso/9780199827282.003.0001

$\mathrm{Hu}$, J., \& Gao, X. (2018). Self-regulated strategic writing for academic studies in an English-medium-instruction context. Language and Education, 32(1), 1-20. https://doi.org/10.1080/09500782.2017.1373804

Jang, E.-Y. (2017). "We got rid of her sentence for revenge": Re-viewing secondlanguage learner strategies considering multiple tensions in the ESL classroom. Mind, Culture, and Activity, 24(1), 32-46. https://doi.org/10.1080/10749039.2016.1191518

Lei, X. (2016). Understanding writing strategy use from a sociocultural perspective: The case of skilled and less skilled writers. System, 60, 105-116. https://doi.org/10.5353/th_b4308567

Mak, P., \& Wong, K. M. (2017). Self-regulation through portfolio assessment in writing classrooms. ELT Journal, (May). https://doi.org/10.1093/elt/ccx012

Ong, J. (2014). How do planning time and task conditions affect metacognitive processes of L2 writers? Journal of Second Language Writing, 23, 17-30. https://doi.org/10.1016/j.jslw.2013.10.002

Panadero, E. (2017). A review of self-regulated learning: Six models and four directions for research. Frontiers in Psychology, 8(422), 1-28. https://doi.org/10.3389/fpsyg.2017.00422 
British Journal of Education

Vol.8, Issue 3, pp.161-177, March 2020

Published by ECRTD- UK

Print ISSN: ISSN 2054-6351

Online ISSN: ISSN 2054-636X

Parry, B., \& Taylor, L. (2018). Readers in the round: Children's holistic engagement with texts. Literacy, 52(2), 103-110.

Pelaez-Morales, C. (2017). L2 writing scholarship in JSLW: An updated report of research published between 1992 and 2015. Journal of Second Language Writing, 38(September), 9-19. https://doi.org/10.1016/j.jslw.2017.09.001

Pintrich, P. R. (2000). The role of goal orientation in self-regulated learning. In Monique Boekaerts, P. R. Pintrich, \& M. Zeidner (Eds.), Handbook of selfregulation (pp. 451-502). San Diego, CA: Academic Press.

Pintrich, P. R. (2004). A conceptual framework for assessing motivation and selfregulated learning in college students. Educ. Psychol. Rev., 16, 385-407. https://doi.org/10.1007/s10648-004-0006-x

Riazi, M., Shi, L., \& Haggerty, J. (2018). Analysis of the empirical research in the journal of second language writing at its 25th year (1992-2016). Journal of Second Language Writing, 41, 41-54. https://doi.org/10.1016/j.jslw.2018.07.002

Stapleton, P. (2010). Writing in an electronic age: A case study of L2 composing processes. Journal of English for Academic Purposes, 9(4), 295-307. https://doi.org/10.1016/j.jeap.2010.10.002

Tseng, W.-T., Dornyei, Z., \& Schmitt, N. (2006). A new approach to assessing strategic learning: The case of self-regulation in vocabulary acquisition. Applied Linguistics, 27(1), 78-102. https://doi.org/10.1093/applin/ami046

Wang, W. (2017). Using rubrics in student self-assessment: student perceptions in the English as a foreign language writing context. Assessment and Evaluation in Higher Education, 42(8), 1280-1292. https://doi.org/10.1080/02602938.2016.1261993

Zamel, V. (1983). The composing processes of advanced ESL students: Six case studies. TESOL Quarterly, 17(2), 6-28.

Zhang, X. (2018). Supporting EFL learners' reflective practices through systemic functional linguistic praxis: A longitudinal case study. Educational Sciences: Theory \& Practice, 18(2), 495-513. https://doi.org/10.12738/estp.2018.2.0022

Zimmerman, B. J. (1986). Becoming a self-regulated learner: Which are the key subprocesses? Contemporary Educational Psychology, 11, 307-313. https://doi.org/doi: 10.1016/0361- 476x(86)90027-5

Zimmerman, B. J. (2000). Attaining self-regulated learning: A social-cognitive perspective. In M. Boekaerts, P. Pintrich, \& M. Zeidner (Eds.), Handbook of self-regulation (pp. 13-39). San Diego, CA: Academic Press. 